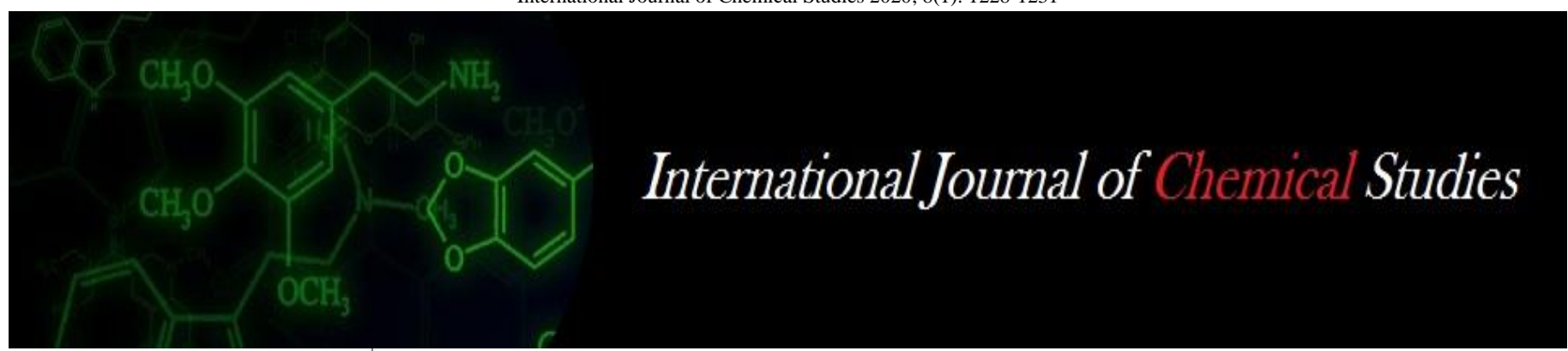

P-ISSN: 2349-8528

E-ISSN: 2321-4902

IJCS 2020; 8(1): 1228-1231

(C) 2020 IJCS

Received: 07-11-2019

Accepted: 09-12-2019

Divyashree KS

Department of Soil Science and Agricultural Chemistry, College of Agriculture, GKVK, UAS, Bengaluru, Karnataka, India

\section{Prakash SS}

Department of Soil Science and Agricultural Chemistry, College of Agriculture, GKVK, UAS, Bengaluru, Karnataka, India

Yogananda SB

Department of Soil Science and Agricultural Chemistry, College of Agriculture, GKVK, UAS,

Bengaluru, Karnataka, India

Chamegowda TC

Department of Soil Science and Agricultural Chemistry, College of Agriculture, GKVK, UAS,

Bengaluru, Karnataka, India

\section{Basavaraja PK}

Department of Soil Science and Agricultural Chemistry, College of Agriculture, GKVK, UAS, Bengaluru, Karnataka, India

\section{Mahadevu P}

Department of Soil Science and Agricultural Chemistry, College of Agriculture, GKVK, UAS, Bengaluru, Karnataka, India

\section{Corresponding Author:}

Divyashree KS

Department of Soil Science and Agricultural Chemistry, College of Agriculture, GKVK, UAS, Bengaluru, Karnataka, India

\section{Response of greengram to soil and foliar application of micronutrients mixture in southern dry zone of Karnataka}

\author{
Divyashree KS, Prakash SS, Yogananda SB, Chamegowda TC, \\ Basavaraja PK and Mahadevu P
}

DOI: https://doi.org/10.22271/chemi.2020.v8.i1q.8418

\begin{abstract}
The productivity of pulses are declining year by year due to many reasons. The major one is as they are grown in rainfed areas with low moisture availability combined with low fertile soils and another important physiological constraint which limit the productivity is flower drop. Experiment was laid out in RCBD with fourteen treatments including control, RDF + FYM, foliar application of MM at 20 DAS (MMF1 and MMF2), 40 DAS (MMF1 and MMF2) along with RDF+FYM, Foliar spray at 20 and 40 DAS along with FYM+RDF and soil application of MMS1, MMS2, MMS3 and MMS4 along with RDF+FYM. These treatments were replicated thrice. Micronutreints mixture comprising $\mathrm{Fe}(20.10 \mathrm{~g})$, Mn (18.20 g), Zn (160 g), Cu (12.73 g), with B (43.70 g)/without B, Mo(2.33 g) was prepared using appropriate micronutrients salts for foliar application per acre and $\mathrm{Fe}(80.4 \mathrm{~g}), \mathrm{Mn}(72.8 \mathrm{~g}), \mathrm{Zn}(640 \mathrm{~g}), \mathrm{Cu}$ $(50.92 \mathrm{~g})$, with B $(174.8 \mathrm{~g}) /$ without B, Mo $(9.32 \mathrm{~g})$ for MMS1 and two, three and four times that of MMS1 for other mixture (MMS2, MMS3 and MMS4, respectively) per acre for soil application. Results revealed that foliar application of MMF1 at 20 days after sowing and MMF2 at 40 days after sowing along + RDF+FYM recorded significantly higher plant height $(28.35 \mathrm{~cm})$, number of leaves per plant (6.87) number of branches per plant (4.13), number of pods per plant (26.42), number of seeds per pod (13.15) and seed yield $\left(1030.70 \mathrm{~kg} \mathrm{ha}^{-1}\right)$ and dry matter $\left.\left(15.61 \mathrm{~g} \mathrm{plant}^{-1}\right)\right)$ of blackgram. While higher haulm yield (1873.75 $\left.\mathrm{kg} \mathrm{ha}^{-1}\right)$ and was observed with MMS2 + RDF+FYM.
\end{abstract}

Keywords: Greengram, soil, foliar application, micronutrients mixture

\section{Introduction}

Agriculture still remains the backbone of Indian economy in spite of various technological advancements and industrial development with $70 \%$ of people dependent on agriculture and $25 \%$ of country's Gross Domestic Product coming from agricultural sector. Among the various inputs in agriculture, fertilizer is a vital input since it replenishes the nutrients removed from the soil by crops and also boosts the yield of crops. Pulses play an important role in Indian agriculture. In India, pulses are being cultivated over an area of 23.6 million hectares with an annual production of 17.2 million tonnes and productivity of $728 \mathrm{~kg}$ per hectare. Greengram [Vigna radiata (L.) Wilczek] also known as mungbean is an important pulse crop of India. It is also considered as "Golden Bean" because of its nutritional value (Its seed contains $24.2 \%$ protein, $1.3 \%$ fat and $60.4 \%$ carbohydrate) and suitability for increasing the soil fertility by way of addition of nitrogen (30 kg ha-1 annum-1). Among all pulses grown in India, greengram ranks third after chickpea and pigeon pea, with a production of $1.49 \mathrm{mt}$. from $3.53 \mathrm{~m}$ ha area (Anon., 2012) ${ }^{[1]}$. Foliar feeding of nutrients has become an established procedure in crop production to increase yield and quality of crop products and it also minimizes environmental pollution and improves nutrient utilization through reducing the amounts of fertilizers added to the soil.

\section{Material and methods}

Field experiment was conducted during early Kharif 2017 on sandy loam soil at College of Agriculture, V.C. Farm, Mandya, University of Agricultural Sciences, Bengaluru, Karnataka to study the effect of micronutrients mixture application on growth and yield of greengram in Southern Dry Zone (Zone 6) of Karnataka. 
The experiment was laid out in RCBD with fourteen treatments including control, RDF + FYM, foliar application of MMF1 and MMF2 at 20 DAS, MMF1 and MMF2 at 40 DAS along with RDF+FYM and their combinations and soil application of MMS1, MMS2, MMS3 and MMS4 along with RDF+FYM. Initial soil properties of the experimental site during 2017 was presented in the Table 1.

Table 1: Initial Physico-chemical properties of the soil

\begin{tabular}{|c|c|c|}
\hline Sl. No & Parameter & Site 1 (2017) \\
\hline \multicolumn{3}{|c|}{ I. Physical properties } \\
\hline & Coarse sand (\%) & 55.70 \\
\hline & Fine sand $(\%)$ & 25.87 \\
\hline & Silt $(\%)$ & 14.9 \\
\hline & Clay $(\%)$ & 3.53 \\
\hline & Textural Class & Sandy loam \\
\hline \multicolumn{3}{|c|}{ II. Chemical properties } \\
\hline 1 & $\mathrm{pH}(1: 2.5)$ & 7.39 \\
\hline 2 & $\mathrm{EC}\left(\mathrm{dS} \mathrm{m} \mathrm{m}^{-1}\right)$ & 0.13 \\
\hline 3 & Organic carbon $\left(\mathrm{g} \mathrm{kg}^{-1}\right)$ & 1.53 \\
\hline 4 & Available $\mathrm{N}\left(\mathrm{kg} \mathrm{ha}^{-1}\right)$ & 252.97 \\
\hline 5 & Avail. $\mathrm{P}_{2} \mathrm{O}_{5}\left(\mathrm{~kg} \mathrm{ha}^{-1}\right)$ & 45.8 \\
\hline 6 & Avail. $\mathrm{K}_{2} \mathrm{O}\left(\mathrm{kg} \mathrm{ha}^{-1}\right)$ & 345.96 \\
\hline 7 & Exch. Ca $\left(\mathrm{cmol} \mathrm{ha}^{-1}\right)$ & 3.24 \\
\hline 8 & Exch.Mg (cmol ha $\left.{ }^{-1}\right)$ & 1.89 \\
\hline 9 & Available $\mathrm{S}\left(\mathrm{mg} \mathrm{kg}^{-1}\right)$ & 15.67 \\
\hline 10 & DTPA Fe $\left(\mathrm{mg} \mathrm{kg}^{-1}\right)$ & 17.82 \\
\hline 11 & DTPA Zn $\left(\mathrm{mg} \mathrm{kg}^{-1}\right)$ & 0.52 \\
\hline 12 & DTPA Mn $\left(\mathrm{mg} \mathrm{kg}^{-1}\right)$ & 8.78 \\
\hline 13 & DTPA Cu $\left(\mathrm{mg} \mathrm{kg}^{-1}\right)$ & 0.53 \\
\hline 14 & Hot water soluble Boron $\left(\mathrm{mg} \mathrm{kg}^{-1}\right)$ & 0.46 \\
\hline
\end{tabular}

Table 2: Micronutrient carrier and content of micronutrient in the mixture used in different crops

\begin{tabular}{|c|c|c|c|c|c|c|c|}
\hline Micronutrients salts used & Form & MMF1 $\left(\mathrm{g} \mathrm{ha}^{-1}\right)$ & MMF2 $\left(\mathrm{g} \mathrm{ha}^{-1}\right)$ & MMS1 $\left(\mathrm{g} \mathrm{ha}^{-1}\right)$ & MMS2 $\left(\mathrm{g} \mathrm{ha}^{-1}\right)$ & $\operatorname{MMS3}\left(\mathrm{g} \mathrm{ha}^{-1}\right)$ & MMS4 $\left(\mathrm{g} \mathrm{ha}^{-1}\right)$ \\
\hline $\mathrm{Fe}_{2} \mathrm{SO}_{4} .7 \mathrm{H}_{2} \mathrm{O}$ & $\mathrm{Fe}$ & 50.25 & 50.25 & 100.5 & 201 & 100.5 & 201 \\
\hline $\mathrm{MnSO}_{4} .5 \mathrm{H}_{2} \mathrm{O}$ & $\mathrm{Mn}$ & 45.5 & 45.5 & 91 & 182 & 91 & 182 \\
\hline $\mathrm{ZnSO}_{4} .7 \mathrm{H}_{2} \mathrm{O}$ & $\mathrm{Zn}$ & 400 & 400 & 800 & 1600 & 800 & 1600 \\
\hline $\mathrm{CuSO}_{4} .7 \mathrm{H}_{2} \mathrm{O}$ & $\mathrm{Cu}$ & 31.82 & 31.82 & 63.64 & 127.28 & 63.64 & 127.28 \\
\hline Sodium molybdate & Mo & 5.82 & 5.82 & 11.64 & 23.28 & 11.64 & 23.28 \\
\hline Boric acid & $\mathrm{B}$ & - & 109.25 & 218.5 & 437 & - & - \\
\hline
\end{tabular}

*MMS-micronutrients mixture for soil application, MMF-micronutrients mixture for foliar application

Recommended dose of NPK (25:50:50 $\left.\mathrm{kg} \mathrm{ha}^{-1}\right)$ for greengram was supplied with urea, single super phosphate and murate of potash, respectively and micronutrient mixture (MMS1 and MMS2) comprising Fe, Mn, Zn, Cu, B and Mo (Table 2) was applied at the time of sowing in the form of iron sulphate, manganese sulphate, zinc sulphate, copper sulphate, borax and sodium molybdate, respectively. Micronutrient mixture containing the amount as indicated in Table 2 for foliar spray was prepared by dissolving the appropriate quantity of all the micronutrient salts in distilled water. Then the $\mathrm{pH}$ of the solution was adjusted to 6.5 using $1 \% \mathrm{KOH}$ solution. This solution was used for foliar spraying (@500 1/ha) at 20 and 40 DAS as per the treatment plan. Crop was harvested at proper maturity. Periodical and quantitative observations were taken in order to assess the effect of micronutrients mixture on growth, yield and yield parameters. Mature pods were harvested manually by hand picking. The seed was separated by manual threshing. Seed and haulm yield was recorded separately treatment wise.

\section{Results and Discussion}

Table 3: Effect of micronutrients mixture application on growth parameters of greengram

\begin{tabular}{|c|c|c|c|c|}
\hline Treatments & Plant height $(\mathbf{c m})$ & Number of leaves per plant & Number of branches per plant & Dry matter production per plant (g plant $\left.\mathbf{~}^{-1}\right)$ \\
\hline $\mathrm{T}_{1}$ & 18.20 & 4.80 & 2.47 & 14.03 \\
\hline $\mathrm{T}_{2}$ & 25.07 & 5.65 & 2.87 & 15.03 \\
\hline $\mathrm{T}_{3}$ & 25.40 & 5.73 & 2.93 & 15.90 \\
\hline $\mathrm{T}_{4}$ & 24.41 & 5.33 & 3.20 & 13.46 \\
\hline $\mathrm{T}_{5}$ & 21.23 & 5.35 & 3.46 & 15.66 \\
\hline $\mathrm{T}_{6}$ & 25.89 & 5.40 & 3.58 & 15.61 \\
\hline $\mathrm{T}_{7}$ & 28.35 & 6.87 & 4.13 & 14.99 \\
\hline $\mathrm{T}_{8}$ & 22.46 & 5.73 & 3.07 & 14.78 \\
\hline $\mathrm{T}_{9}$ & 25.44 & 6.51 & 2.99 & 16.34 \\
\hline $\mathrm{T}_{10}$ & 24.73 & 6.20 & 3.28 & 14.61 \\
\hline $\mathrm{T}_{11}$ & 21.13 & 5.27 & 3.08 & 16.21 \\
\hline $\mathrm{T}_{12}$ & 24.67 & 6.53 & 3.67 & 14.69 \\
\hline $\mathrm{T}_{13}$ & 22.84 & 6.53 & 3.24 & \\
\hline
\end{tabular}




\begin{tabular}{|c|c|c|c|c|}
\hline $\mathrm{T}_{14}$ & 22.76 & 5.60 & 3.04 & 15.33 \\
\hline $\mathrm{SEm} \pm$ & 1.10 & 0.25 & 0.16 & 0.64 \\
\hline $\mathrm{CD}(\mathrm{p}=0.05)$ & 3.20 & 0.72 & 0.47 & 1.88 \\
\hline
\end{tabular}

Effect of application of micronutrients mixture on growth and yield of greengram was significant (Table 3). Significantly higher plant height was noticed in $\mathrm{T}_{7}(28.35 \mathrm{~cm})$ with the application of RDF + FYM + MMF1 at $20 \mathrm{DAS}+\mathrm{MMF} 2$ at 40 DAS and it was on par with $\mathrm{T}_{6}$ and $\mathrm{T}_{9}$ and significantly differed from other treatments. Highest number of leaves (6.87) and branches (4.13) per plant recorded with the application of RDF + FYM + MMF1 at 20 DAS+ MMF2 at 40 DAS and these treatments were on par with $\mathrm{T}_{12}(6.53$ and 3.67 respectively) with RDF + FYM + MMS2 and lowest was recorded in control (4.80 and 2.47 respectively).Significantly higher dry matter production per plant $(16.21 \mathrm{~g})$ was observed with RDF + FYM + MMS2 application.

The growth parameters and dry matter production in both greengram and blackgram recorded with the application of micronutrients mixture along with FYM + RDF were significantly higher than that recorded with only FYM+RDF. Micronutrients play an important role as these are involved in metabolic functions, translocation, enzyme activation, cell multiplication, photosynthesis etc., thus application of micronutrients mixture either through soil or foliage enhanced the growth parameters and dry matter production in greengram. The similar beneficial effect of multi micronutrients mixture application have been reported by Kannan et al., (2014) ${ }^{[4]}$ and Poongothai and Chitdeshwari (2003) [5] in blackgram, by Hemn (2013) ${ }^{[3]}$ in cowpea, by Valenciano et al. (2010) ${ }^{[8]}$ in chickpea and by Quddus et al. $(2011)^{[6]}$ in mungbean.

Table 4: Effect of micronutrients mixture application on yield and yield attributes of greengram

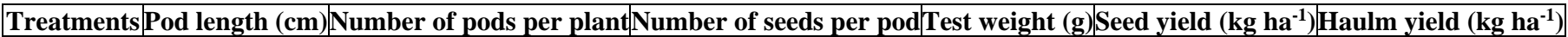

\begin{tabular}{|c|c|c|c|c|c|c|}
\hline & & & & & & \\
\hline $\mathrm{T}_{1}$ & 6.31 & 17.61 & 9.87 & 4.01 & 680.43 & 765.93 \\
\hline $\mathrm{T}_{2}$ & 7.53 & 21.49 & 11.26 & 4.17 & 895.75 & 1271.07 \\
\hline $\mathrm{T}_{3}$ & 7.60 & 20.97 & 11.55 & 4.17 & 846.52 & 1609.34 \\
\hline $\mathrm{T}_{4}$ & 7.32 & 20.88 & 11.87 & 4.10 & 920.15 & 1581.09 \\
\hline $\mathrm{T}_{5}$ & 7.35 & 19.42 & 10.73 & 4.14 & 921.04 & 1592.13 \\
\hline $\mathrm{T}_{6}$ & 7.39 & 24.11 & 12.87 & 4.15 & 1015.36 & 1643.11 \\
\hline $\mathrm{T}_{7}$ & 7.99 & 26.42 & 13.15 & 4.26 & 1030.70 & 1656.47 \\
\hline $\mathrm{T}_{8}$ & 7.66 & 24.05 & 12.17 & 4.10 & 921.65 & 1347.83 \\
\hline $\mathrm{T}_{9}$ & 7.73 & 20.66 & 12.21 & 4.11 & 939.33 & 1510.44 \\
\hline $\mathrm{T}_{10}$ & 7.21 & 20.14 & 10.96 & 4.08 & 983.16 & 1518.51 \\
\hline $\mathrm{T}_{11}$ & 7.68 & 22.23 & 11.67 & 4.11 & 809.69 & 1559.96 \\
\hline $\mathrm{T}_{12}$ & 7.88 & 21.09 & 11.69 & 4.07 & 927.49 & 1873.75 \\
\hline $\mathrm{T}_{13}$ & 6.74 & 21.72 & 11.68 & 4.25 & 912.04 & 1631.78 \\
\hline $\mathrm{T}_{14}$ & 7.28 & 20.88 & 11.91 & 4.04 & 902.99 & 1486.38 \\
\hline SEm \pm & 0.36 & 1.02 & 0.55 & 0.06 & 42.74 & 74.47 \\
\hline $\mathrm{CD}(\mathrm{p}=0.05)$ & 1.06 & 2.98 & 1.60 & 0.18 & 124.25 & 216.49 \\
\hline
\end{tabular}

The data on the effect of application of FYM + RDF and micronutrients mixture on yield attributes and yield of greengram are presented in Table 4.Yield and yield attributes were differed significantly with the application of micronutrients mixture along with RDF + FYM. Significantly higher pod length $(7.99 \mathrm{~cm})$, number of pods per plant $(26.42)$, number of seeds per pod (13.15), Test weight (4.26 g) were recorded with the application of RDF + FYM + MMF1 at 20 DAS + MMF2 at 40 DAS and lowest was observed with control, RDF + FYM. Superior yield of $1030.70 \mathrm{~kg} \mathrm{ha}^{-1}$ was observed in $\mathrm{T}_{7}$ significantly and it was on par with other treatments except $T_{1}, T_{2}, T_{3}, T_{11}$ and $T_{14}$. Significantly higher haulm yield was observed in $\mathrm{T}_{12}\left(1873.75 \mathrm{~kg} \mathrm{ha}^{-1}\right)$ compare to all other treatments.

Foliar application of micronutrients ( $\mathrm{Fe}, \mathrm{Mn}, \mathrm{Zn}, \mathrm{Mo}, \mathrm{Cu}$, with/without B) resulted in effective absorption of the nutrients during critical stages of growth and in turn contributed to increased pod length. This result was in accordance with the earlier findings of Sarkar and Malik (2001) ${ }^{[7]}$. Foliar application of nutrients enhanced the number of floral buds, prevented the floral shedding by maintaining optimum bio - physiological conditions and also these micronutrients such as $\mathrm{Fe}, \mathrm{Zn}$ and $\mathrm{Mn}$ have a structural role in chlorophyll. Consequently supply of these micronutrients enhances the chlorophyll content ultimately photosynthesis. This in turn, leads to an increase in yield attributes in the treatment that received micronutrients mixture (Farag et al.,
2014) ${ }^{[2]}$ and B in the mixture might have improved flower retention, pollination and sugar transportation. Thus the total effect of application micronutrients mixture resulted in higher yield attributes and yield in greengram.

\section{Conclusion}

The results indicated that soil or foliar application of micronutrients mixture along with RDF+FYM can significantly enhance the growth, yield and nutrient content of greengram. Application of micronutrients mixture ensures the balanced supply of nutrients which in turn helps in improving the nutritional quality of crops.

\section{Acknowledgement}

Department of science and Technology, Ministry of Science and Technology Government of India for awarding INSPIRE fellowship to carry out the research as part of Doctoral Degree program of corresponding author.

\section{References}

1. Anonymous. FAO Bull. Stat, Statistics Division of Economics and Social Department. 2012; 2:54.

2. Farag IAA, Eliwa NE, Khawaga AAHE. Importance of gamma irradiation, micronutrient mixtures and their application methods for improving faba bean (Vicia faba L) growth and yield. J Agri. Veter. Sci. 2014; 7(7):48-57. 
3. Hemn OS. Effect of Foliar Fertilization of Fe, B and Zn on nutrient concentration and seed protein of Cowpea Vigna unguiculata. J Agri. Vet. Sci. 2013; 3:42-46.

4. Kannan P, Arunachalam P, Prabukumar G, Prabhaharan J. Response of Blackgram (Vigna Mungo L.) to multi micronutrients mixtures under Rainfed Alfisol J Indian Soc. Soil Sci. 2014; 62(2):154-160.

5. Poongothai S, Chitdeshwari T. Response of blackgram to multi micronutrients mixture. Madras Agric. J. 2003; 90(7-9):442-443.

6. Quddus MA, Rashid MH, Hossain MA, Naser HM. Effect of zinc and boron on yield and yield contributing characters of mungbean in low ganges river floodplain soil at madaripur, Bangladesh. Bangladesh J Agril. Res. 2011; 36(1):75-85.

7. Sarkar R, Malik G. Effect of foliar spray of potassium nitrate and calcium nitrate on grasspea (Lathyrus sativus L.) grown in rice fallows. Lathyrus Lathyrism Newsletter, 2001; 2:47.

8. Valenciano JB, Boto JA, Marcelo V. Response of chickpea (Cicer arietinum L.) yield to zinc, boron and molybdenum application under pot conditions. Spanish J Res. 2010; 8(3):797-807. 